Review Article

\title{
Role of Microalgae as a Source for Biofuel Production in the Future: A Short Review
}

\author{
Mustafa Jawad Nuhma1,2, Hajar Alias', Ali A. Jazie², Muhammad Tahir ${ }^{1, *)}$ \\ ${ }^{1}$ Department of Chemical Engineering, School of Chemical and Energy Engineering, \\ Universiti Teknologi Malaysia, 81310 UTM Johor Bahru, Johor Malaysia. \\ ${ }^{2}$ Chemical Engineering Department, Engineering College, University of Al-Qadisiyah, \\ Al-Qadisiyah, Al-Diwaniyah, Iraq.
}

Received: $2^{\text {nd }}$ March 2021; Revised: $6^{\text {th }}$ Apr 2021; Accepted: $6^{\text {th }}$ April 2021

Available online: $8^{\text {th }}$ April 2021; Published regularly: June 2021

\section{Abstract}

The continued burning of fossil fuels since the beginning of the last century led to higher emissions of greenhouse gases and thus leads to global warming. Microalgae are one of the most important sources of green hydrocarbons because this type of algae has a high percentage of lipids and has rapid growth, consumes the carbon dioxide in large quantities. Besides, the cultivation of these types of algae does not require arable land. This review aims to explain the suitability of microalgae as a biofuel source depending on the fat content, morphology, and other parameters and their effect on the conversion processes of microalgae oil into biofuels by different zeolite catalytic reactions. It also discusses in detail the major chemical processes that convert microalgae oil to chemical products. This review sheds light on one of the most important groups of microalgae (Chlorella vulgaris microalgae). This review includes a historical overview and a comprehensive description of the structure needed to develop this type of algae. The most important methods of production, their advantages and disadvantages are also deliberated in this work.

Copyright (C) 2021 by Authors, Published by BCREC Group. This is an open access article under the CC BY-SA License (https://creativecommons.org/licenses/by-sa/4.0).

Keywords: Biofuels; Zeolite; Rare earth metals; Microalgae; Deoxygenation

How to Cite: M.J. Nuhma, H. Alias, A.A. Jazie, M. Tahir (2021). Role of Microalgae as a Source for Biofuel Production in the Future: A Short Review. Bulletin of Chemical Reaction Engineering \& Catalysis, 16(2), 396-412 (doi:10.9767/bcrec.16.2.10503.396-412)

Permalink/DOI: https://doi.org/10.9767/bcrec.16.2.10503.396-412

\section{Introduction}

The limited reserves of fossil fuels and global warming caused by excessive carbon dioxide emissions have sparked global research on alternative and sustainable energy sources [1]. Therefore, microalgae as characterized by the efficiency of photosynthesis, grow rapidly, consume large quantities of carbon dioxide and produce large quantities of oxygen gas can contrib-

* Corresponding Author.

Email: mtahir@cheme.utm.my (M. Tahir);

Telp: +60 14-628 1678 ute to reducing the effects of global warming [2]. Microalgae can grow all over the world, where they can grow in the Scandinavian soil where the temperature is low and also possible to grow in desert soils where the temperatures are high and also possible to grow in freshwater and saltwater [3], we can say that microalgae can grow in all environmental conditions on the earth's surface. Microalgae are a promising and important resource for renewable energy due to their high content of triglycerides up to $60 \%$ [4].

Several studies have been conducted regarding the possibility of producing biofuels from mi- 
croalgae fat to contribute to reducing the total dependence on fossil fuels [5]. Fat content and fat efficiency depend on several factors: microalgae types, planting conditions, and growth conditions [6]. A study conducted on the Chlamydomonas debaryana microalgae showed that the catalytic pyrolysis process of this biomass using $\beta$-zeolite for the removal of nitrogen and the production of aromatics showed that $\beta-$ zeolite catalyzed pyrolysis produced higher yields of total hydrocarbons (aromatic + aliphatic) [7]. The quality of the biofuel extracted from Chlorella vulgaris (C. vulgaris) microalgae in the catalytic pyrolysis process using zeolite supported by $\mathrm{Ni}$, this study showed that the biofuel contains high hydrocarbon quantities that are highly acidic with fewer oxygen quantities compared to the non-catalytic pyrolysis process [8].

Numerous studies have investigated the possibility of improving the selectivity and stability of zeolites where rare earth metals have been added to zeolites [9-13]. In conclusion, the effect of the rare earth metals modified zeolite catalyst will offer efficient deoxygenation reactions to produce high-quality biofuels due to improved activity, selectivity, and stability of catalyzing simultaneous reactions.

The present review shed the light on the possible usability and challenges in the use of microalgae as a source of energy towards the reduction of total energy cost. Moreover, microalgae morphology, the techniques of production, growths of microalgae, microalgae composition and extraction techniques for the microalgae crude oil production have been deliberated. The effect of the microalgae lipid content and quality of bio-crude oil are also highlighted. Recent production technologies of the microalgae biofuels from bio-crude oil have been discussed. Special incite has been devoted to the different zeolite materials and modified zeolite used for the deoxygenation and hydrodeoxygenation processes. Finally, the role of rare earth metals was found the right choice for enhancing the activity, selectivity, and stability of the zeolite catalyst as a novel route in the deoxygenation and hydrodeoxygenation processes.

\section{Microalgae Biomass}

The selection of microalgae strains with high lipid content to obtain large amounts of biofuels is an important issue. The characterization and analysis of the fats are one of the most critical pre-studies measures on biofuels production from microalgae. It helps to determine this strain's suitability to produce biofu- els. The profile of the carbon chains for some microalgae species is found in other literature [14]. The main challenges that accompany the production process are the costs of agriculture, harvesting, and drying. There are types of microalgae where the fat content is relatively low. There is a great need to improve the fat content in some low-fat species using techniques that help to grow fatter, such as partial or total starvation of nutrients. There are some researches has shown the use of nonpolar lipids and polar lipids present in microalgae to generate different types of biofuels from transesterification and has shown positive results in this area. Besides, the lipid composition can be modified by changing the growth conditions, especially in the case of nonpolar fats to produce good quality biofuels.

\section{Obstacles to Using Microalgae Biomass}

There are three types of challenges facing the production of some types of biofuels extracted from microalgae: biological, chemical, and mechanical. Concerning biological challenges, the selection of the appropriate strain is very important for the production of biofuels in greater quantity and better quality as each strain has its fat content. Fat content can affect the productivity and quality of biofuels. Besides, good agricultural conditions should be provided for microalgae to improve growth rates, improve fat productivity, and improve the photosynthetic efficiency of these microalgae. The chemical challenges associated with the production of biofuels from microalgae are related to the extraction of solvent oil, chemical harvesting, and water quality. The main mechanical challenges associated with the production of biofuels are maintenance, costs associated with planting, harvesting, drying, and recovery of oil. All these problems result in the development of microalgae jet fuel make this process more difficult but can be easily produced if an effective design plan is reached [15].

\section{Microalgae Morphology}

Microalgae have a wide morphological diversity. The simplest forms are in the form of microscopic cells or single-cell, nonmotile, or motile cells. They can be spherical shape or pyriform, non-motile or motile algae may form a colony, known as a coenobium. Fat content and fat efficiency depend on several factors: microalgae types, planting conditions, and growth conditions. Fat content can affect the productivity and quality of biofuels. C. vulgaris 
is a spherical microscopic cell with a diameter of 2-10 microns and does have a lot of structural components analogous to crops. Figure 1 shows the general structure components of the microalgae cell [16].

\subsection{Cell Wall}

C. vulgaris is a spherical microscopic cell with a diameter of $2-10$ microns [17], it has many structural components similar to the structural components of the plants. Its stiffness keeps the cell safe by protecting it from invaders and harsh conditions. This hardness changes from one stage to another during the stages of cell growth. The cell wall of the daughter's cell gradually thickens to reach about from $(17-21)$ nanometer after the ripening, a layer of microfibrillar is created, which is a Chitosan-like glucosamine layer, it is a source of cell stiffness [18]. The thickness and structure of the cell wall vary depending on the conditions of development and climate. Besides, some studies [19] have demonstrated the cell wall's rigidity by highlighting a layer's presence of sporopollenin, the cell wall consists of a single layer free of sporopollenin.

\subsection{The Cytosol}

The cytosol is a gel substance that is confined present inside the cell membrane, it consists of also contains some minerals, water, and proteins. C. vulgaris hosts internal organs such as mitochondria, vacuoles, small nuclei [20], Golgi body, and single green chloroplasts [21].

\subsubsection{The Mitochondrion}

Some genetic components are present in the mitochondrion, and consist of the respiratory tract, the outer membrane of the double layer membrane covers the entire organic organism,

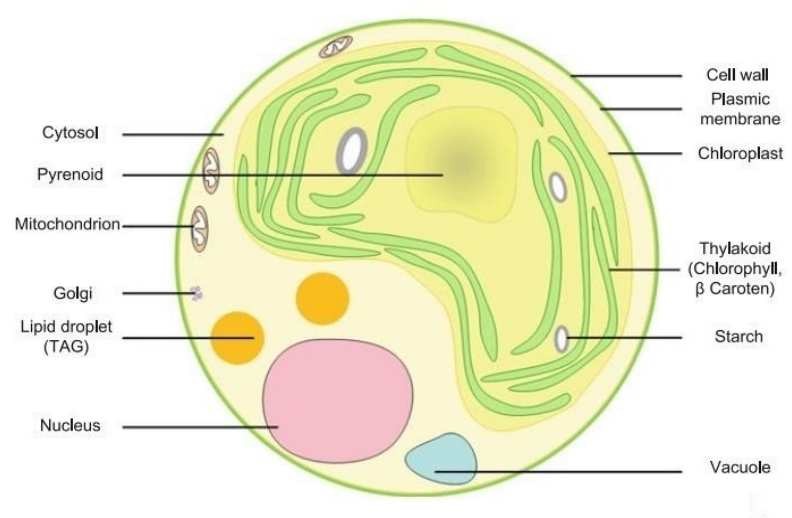

Figure 1. Structure of the microalgae cell [16]. this membrane consists of the equivalent protein and phospholipid ratio [21]. However, the inner membrane is three times more proteins than phospholipid, it surrounds the inner space called the matrix, which includes most mitochondrial proteins.

\subsubsection{The Chloroplast}

C. vulgaris contain chloroplasts monoculars, it is coated with a dual film of the phospholipid, the outer film is effective for ions and metabolites, while the inner film function transfers special types of proteins. The composition of the starch granules, which consists of amylose and amylopectin where they are configured within a private chloroplast in inappropriate growth conditions. The pyrenoid is the basis of carbon dioxide stabilization and contains elevated levels of ribulose-1,5-bisphosphate carboxylase oxygenase (RuBisCO). A group of fused thylakoids is also stored in chloroplasts where chlorophyll is manufactured, the dominant pigment to mask the color of other pigments such as lutein. Fat pellets accumulate primarily in the cytoplasm and chloroplasts during nitrogen stress [22].

\section{Production and Growth Techniques}

\subsection{Production}

In general, microalgae can photosynthesize and produce their nutritional use of carbon dioxide and sunlight to generate oxygen and carbohydrates. In 2009, Chlorella was produced by 2,000 tons (dry weight) and was mainly produced in Japan, Germany, and Taiwan [23]. These microalgae have rapid growth rates and can grow in extreme weather conditions and adapt to these inappropriate conditions. C. vulgaris is exemplary for preparation, this is due to its resistance to extreme conditions and invaders. On the other hand, the fat content and the starch content increase. As for the biomass efficiency, it stops or reduces through improper growth conditions [24], such as nitrogen and phosphorus restriction, the concentration of high carbon dioxide, excessive exposure to light [25-27], average iron overload [28], or increased temperatures [29]. Moreover, the contents of protein improve through controlled and normal outgrowth conditions (Supplements of $\mathrm{N}_{2}$ ). Thus, several methods of cultivation and growth of this type of microalgae have been examined to improve the content of biomass, fats, proteins, pigment content, and carbohydrates. 


\subsection{Growths}

\subsubsection{The Autotrophic Growth}

\subsubsection{The Open Pond}

The open pond systems are the ultimately used manufacturing technique, they are the cheapest technology for huge biomass production. These systems are classified into natural waters (lakes, salt lakes, and ponds), containers, artificial containers, and wastewater. They are generally built next to heavy industries or power plants, where they release huge amounts of carbon dioxide. This biomass of the algae absorbs nitrogen from the atmosphere in the form of nitrogen oxides. The ideal depth of the pond is about more than $14 \mathrm{~cm}$ and less than $51 \mathrm{~cm}$, to enable all cells to be exposed to the light of the sun, essentially after the end of the exponential growth period [23,29]. Otherwise, these systems, when established, require several restrictions as to their need stringent environmental monitoring to reduce the jeopardy of contamination, evaporation of water, pollutants, etc., also to prevent the growth of some undesirable algae. Moreover, the variations of temperature cannot be controlled due to seasonal variations from one season to another, it is difficult to control the concentration of carbon dioxide and excess sun exposure. Furthermore, several of the cells are not enough open to the light of the sun because they are covered by the cells which are close to the surface, resulting in a decrease in biomass to be produced. Therefore, it is better to mix the water medium from time to time and this is what is working now.

\subsubsection{The Closed Photo-Bioreactor}

The closed photo-bioreactor is used to beat several of the elements that affect the production in the systems of open ponds, thereby increasing the biomass in controlled surroundings such as $\mathrm{pH}$, temperature, the intensity of the light, and $\mathrm{CO}_{2}$ concentration, to get a high concentration in cells besides the production of the most suitable products for manufacturing the pure pharmaceuticals, nutrients, etc. Moreover, they are suitable for weak strains that cannot contend, develop, and expand in hostile environments. The biomass is fed via pumping carbon dioxide into the bubbles of the tubes where the biomass feeds well. If the tubes are not exposed to sufficient sunlight, fluorescent lamps are used. The diameter of the tubes is usually $20 \mathrm{~cm}$ or less [30], the thickness of their pellucid walls is a small millimeter, permitting sufficient light to be absorbed. Therefore, mul- tiple designs were used and tested: flat-panel photobioreactors, column photobioreactors, and tube photobioreactors [31]. Degen et al. attained $0.11 \mathrm{~g} . \mathrm{L}^{-1} \cdot \mathrm{h}^{-1}$ of dry biomass output next to the growth of $C$. vulgaris cells in an equable panel photobioreactor under constant lighting $\left(980 \mu \mathrm{E}^{-\mathrm{m}^{-2}} . \mathrm{s}^{-1}\right)$ [32]. However, the major disadvantages of these systems are the high cost of construction, the little lighting space, and sterilization price.

\subsubsection{The Heterotrophic Growth}

The light is not used in this method, the organic carbon source of biomass is provided. Consequently, microalgae are produced in the mixed bioreactor or fermenter and the bigger biomass is expected to be obtained in greater quantity and efficiency, in addition to lower gathering costs because of increased dried biomass up to $0.25 \mathrm{~g} . \mathrm{L}^{-1} \cdot \mathrm{d}^{-1}[33,34]$. The high levels of accumulation of various elements like fats $22-54 \mathrm{mg} . \mathrm{L}^{-1} \cdot \mathrm{d}^{-1}$ are the sources of carbon used to produce $C$. vulgaris from acetate, glucose, glutamate, and glycerol, the highest particular rate of outgrowth of C. vulgaris can be gained with the glucose. However, the main abuse of this method is the high cost, accessibility of sugars that contend with raw materials for different uses like food production and biofuels.

\subsubsection{The Mixotrophic Growth}

C. vulgaris can combine heterotrophic and autotrophic methods by photosynthesis and also by utilizing organic products such as glucose that are most suitable for C. vulgaris $[33,35]$. The growth of the cells does not depend entirely on the light or the excretion of organic matter. This technicality contends favorably with the systems of autotrophic, in the opinion of Yeh and Chang, this study appeared a combination of raise dry of the biomass yield (2-5 g. $\left.\mathrm{L}^{-1} \cdot \mathrm{d}^{-1}\right)$ and fat output (67-144 mg. $\left.\mathrm{L}^{-1} \cdot \mathrm{d}^{-1}\right)$ [35]. One of the major benefits of mixotrophic metabolism is its active contribution to reducing the effect of biomass damage through dark breathing, decrease the quantities of organic substrates used for the production of biomass.

\subsubsection{The Other Growth Techniques}

The outgrowth of the $C$. vulgaris can occupy another proportion by immobilizing it in the alginate beads with the bacteria of the Azospirillum brassillins [36,37]. This technique was interpolated to $C$. vulgaris and other microalgae from the supposition that Azospirillum bra- 
silense enhances the performance of terrestrial plant growth by interfering with the hormonal metabolism of the host plant and provides $\mathrm{O}_{2}$ for bacteria to biodegradable pollutants and then microalgae consume carbon dioxide from bacterial respiration [38]. Thus, depending on the C. vulgaris strain [37], this technique affects the prolongation of the life of this species of microalgae, enhanced biomass output, increased cell size $62 \%$ bigger, the accruement of pigments and fats. At the same time, wastewater absorption of zinc, nitrogen, phosphorus, cadmium, and the different weighty metals increases. Also, the increase of C. vulgaris has a pronounced effect on the associative bacteria Phyllobacterium myrsinacearum by stopping its development or cell death [39]. Furthermore, the shear stress and the mixing influence increased photosynthesis action and outgrowth of C. vulgaris. Consequently, optimum conditions (tip velocity $126 \mathrm{~cm} \cdot \mathrm{s}^{-1}$ and rubbing speed $2.06 \mathrm{~cm} . \mathrm{s}^{-1}$ ) increase photosynthesis activity by 4 to $5 \%$ with better growth of 48 to $71 \%$ compared to friction speed or null tip speed [40]. However, the maximum tip speed and high friction speed reduce photosynthesis and growth activity to unsettling state value and even lower.

\section{The Composition of the Microalgae}

\subsection{The Proteins}

The proteins are an important component of algae. They take part in capitalist functions like cell outgrowth, reform, conservation and cellular motors, organizers of cellular actions, chemical messengers, and fighting threats from outside. The overall protein content of grown C. vulgaris is between more than $41 \%$ and less than $59 \%$ of the dry weight of biomass, which changes with the outgrowth situations [41-44]. The proteins have different functions, about $21 \%$ of whole proteins linked to the wall of the cell, more than $50 \%$ inside of the cell, $30 \%$ migrating outside of the cell [45]. The nutritional quality of the protein is determined by its profile of amino acid [45], most of the microalgae, the amino acid of the $C$. vulgaris profile was compared favorably and better with the natural nutrition profile proposed by the World Health Organization, the Food and Agriculture Organization (FAO) because the cells of the $C$. vulgaris synthesis of primary and non-primary amino acids as shown in Table 1.

Protein extraction from microalgae is technically the same for all types of microalgae, it is implemented primarily via dissolving alkaline solutions of the proteins [42,48,49]. How-

Table 1. Chlorella Vulgaris amino acid profile compared to other resources expressed in grams of protein per 100 grams.

\begin{tabular}{lccccc}
\hline \multicolumn{1}{c}{ Amino acids } & $\begin{array}{c}\text { C. vulgaris } \\
{[47]}\end{array}$ & $\begin{array}{c}\text { C. vulgaris } \\
{[42]}\end{array}$ & $\begin{array}{c}\text { Reccomendation from } \\
\text { FAO/WHO }[48,49]\end{array}$ & $\begin{array}{c}\text { Eggs } \\
{[48,49]}\end{array}$ & $\begin{array}{c}\text { Soya } \\
{[48,49]}\end{array}$ \\
\hline Threonline & 5.15 & 6.09 & 4.00 & 4.00 & 5.00 \\
Glutamic acid & 12.66 & 9.08 & N/A & 19.00 & 12.60 \\
Serine & 4.32 & 7.77 & N/A & 5.80 & 6.90 \\
Alanine & 8.33 & 10.90 & N/A & 5.00 & n.d \\
Cysteine & 1.28 & 0.19 & 3.5 & 1.90 & 2.30 \\
Isoleucine & 4.44 & 0.09 & 4.00 & 5.30 & 6.60 \\
Methionine & 1.24 & 0.65 & N/A & 1.30 & 3.20 \\
Tyrosine & 3.14 & 8.44 & 6.00 & 3.20 & 4.20 \\
Leucine & 9.38 & 7.49 & 7.00 & 7.70 & 7.00 \\
Histidine & 1.97 & 1.25 & N/A & 2.60 & 2.40 \\
Phenylalanine & 5.51 & 5.81 & N/A & 5.00 & 5.80 \\
Arginine & 6.22 & 7.38 & N/A & 7.40 & 6.20 \\
Lysine & 6.68 & 6.83 & 5.50 & 6.40 & 5.30 \\
Proline & 4.90 & 2.97 & N/A & 5.30 & 4.20 \\
Glycine & 6.07 & 8.60 & N/A & 4.50 & 4.20 \\
Valine & 6.61 & 3.09 & 5.00 & 5.30 & 7.20 \\
Tryptophan & 2.30 & 0.21 & 1.00 & 1.40 & 1.70 \\
\hline
\end{tabular}

n.d: not detected, N/A: not available 
ever, the elemental analysis and Kjeldahl analysis take into account the complete nitrogen in microalgae and multiply it by the natural nitrogen-to-protein conversion factor (NTP) 6.25 and may overestimate or quantify the true protein intake [50-53]. As a result, several studies have been proposed to calculate the amino acid profile, where a new value of the factor of nitrogen-to-protein conversion (NTP) should be smaller than the normal (6.25).

\subsection{The Lipids}

The fats are a group of heterogeneous compounds that can be identified by dissolving them in the non-polar solvents, they are comparatively insoluble in the water. C. vulgaris can reach between 5 and $40 \%$ fat per dry weight of biomass during optimal growth [54], This biomass consists primarily of glycolipids, hydrocarbons, phosphorus fats, waxes, and fewer quantities of the free fatty acids [55,56]. These combinations are generated via chloroplasts, they are placed on the wall of the cell, as well as on organic films (mitochondrial membranes and chloroplasts) [57]. However, the fat content (mainly consisting of triglycerin) may reach 58\% during inappropriate growth conditions. The whole fat is usually extracted from C. vulgaris using Dyer-Bligh technology, it is an admixture of methanol, hexane, oil oxide, or chloroform [28,58-62]. Total quantification of total fat is carried out after the evaporation of the extracted solvent. Furthermore, a column chromatographic analysis is performed to separate the distinct fat components followed by the evaporation of the solvent and then weigh the residual fat sample [63]. The profile of the fatty acid varies according to the outgrowth conditions, it is appropriate for various uses. For example, Yeh and Chang [35], showed that the profile of the fatty acid in the $C$. vulgaris, which grows in the mixed outgrowth conditions, which be between $60-68 \%$ of monounsaturated fatty acids and consists of the following components: oleic acid (C18:1), Stearic acid (C18:0), palmitic acid (C16:0) and palmitoleic

Table 2. The sugar content of the cell wall of simple polysaccharides [74].

\begin{tabular}{cc}
\hline Percentage (\%) & Neutral sugar \\
\hline $2-9$ & Arabinose \\
$45-54$ & Rhamnose \\
$2-7$ & Mannose \\
$7-19$ & Xylose \\
$1-4$ & Glucose \\
$14-26$ & Galactose \\
\hline
\end{tabular}

acid (C16:1) [58]. This profile considers the most suitable for the manufacture of biodiesel. Conversely, if grown in favorable outgrowth conditions, the profile of the fatty acid indicates that it is unfit to produce biodiesel [64], but is more appropriate for food use because they are rich in fatty acids of the polyunsaturated like (C18:2, C18:3) linolenic acid and (C20:5) eicosapentaenoic acid.

\subsection{The Carbohydrates}

The carbohydrates consist of a collection of reduced sugars, starch-like cellulose, and polysaccharides. In C. vulgaris, starch is the most abundant polysaccharide. In general, it is found in chloroplasts and consists mainly of amylopectin and amylose. The cellulose is a highly resistant structural polysaccharide placed on the wall of the C. vulgaris cell as a preservative fibrous fence. Moreover, The major significant sugars in the C. vulgaris is ( $\beta 1-$ 3) glucan, which has many nutritional and health profits [65]. In general, the entire amount of carbohydrates is estimated using the sulfuric and the phenol method [66,67]. Compared to the acidic technique, the estimation of the amount of starch is better using the enzymatic technique $[68,69]$. Total carbohydrates can achieve a dry weight of 12 to $55 \%$ while reducing nitrogen. The sugar composition of the cell wall as shown in Table 2, is a combination of rhamnose, galactose, glucose, xylose, arabinose, and mannose [70-74], the dominant sugar is rhamnose.

\subsection{The Pigments}

Chlorophyll is one of the more pigmented species in the C. vulgaris, it is located in thylakoid, it can reach $1-2 \%$ of dry weight. The C. vulgaris also contain significant amounts of

Table 3. Potential content of dyes in C. vulgaris under different development conditions.

\begin{tabular}{ccc}
\hline$\mu \mathrm{g} \cdot \mathrm{g}^{-1}$ & Pigments & References \\
\hline 550,000 & Astaxanthin & {$[77-79]$} \\
$7-12,000$ & $\beta$-Carotene & {$[37,77,80-82]$} \\
$52-3830$ & Lutein & {$[37,77,80-82]$} \\
362,000 & Cantaxanthin & {$[77,78,82]$} \\
$72-5770$ & Chlorophyll-b & {$[37,81,82]$} \\
$250-9630$ & Chlorophyll-a & {$[37,80,82]$} \\
N/A & Pheophytin-b & {$[81]$} \\
$10-37$ & Violoxanthin & {$[37]$} \\
$2310-5640$ & Pheophytin-a & {$[81]$} \\
\hline \multicolumn{2}{l}{ N/A: not available }
\end{tabular}


$\beta$-carotene carotenoids as summarized in Table 3 , it acts as supplemental dyes where they capture light, for example, carotene is associated with lipid droplets in chloroplasts, while primary carotenoids bind to chlorophyll in thylakoids where they hunt light energy, then transfer it to the photosystem.

However, as in terrestrial crops, by defending chlorophyll molecules from decomposition and decoloring through strong exposure to oxygen and radiation, some dyes act as photoprotection. These dyes have many important therapeutic characteristics, like antioxidant activity, their preventative effect contra retinal degeneration [81,82], as well as the regulation of cholesterol in the blood and the prevention of chronic diseases such as heart, colon, and vascular cancer and strengthen the immune system of the human body $[83,84]$. Several studies have been carried out to improve the method of pigment extraction by utilizing solvents such as (ethanol, dimethylformamide, acetone, hexane, and dichloromethane), soxhlet, ultrasonic extraction [80,85-88].

\subsection{The Minerals and the Vitamins}

The minerals are determined by atomic absorption spectrometry, where the mineral content of algae biomass is measured in two steps, the first step is burned, then the second step is analyzed as shown in Table 4. These minerals have important functions in the human body [92]. Vitamins are classified into two categories: soluble in water $(\mathrm{C}$ and $\mathrm{B})$ and the other type soluble in fat (A, D, E, and K). C. vulgaris has an important vitamin profile as shown in Table 5, which is essential for the development and differentiation of cells in the body of the

Table 4. The C. vulgaris mineral profile.

\begin{tabular}{|c|c|c|c|}
\hline \multicolumn{4}{|c|}{ Minerals content (g.100 g-1) } \\
\hline References & Panahi et al. [91] & Maruyama et al. [92] & Tokusoglu and Unal [93] \\
\hline \multicolumn{4}{|c|}{ Microelements } \\
\hline $\mathrm{P}$ & 0.96 & N/A & 1.76 \\
\hline $\mathrm{Na}$ & N/A & N/A & 1.35 \\
\hline $\mathrm{Mg}$ & 0.44 & 0.36 & 0.34 \\
\hline $\mathrm{Ca}$ & 0.27 & 0.16 & 0.59 \\
\hline $\mathrm{K}$ & 2.15 & 1.13 & 0.05 \\
\hline \multicolumn{4}{|c|}{ Macroelements } \\
\hline $\mathrm{Cu}$ & 0.19 & N/A & $\operatorname{tr}$ \\
\hline $\mathrm{Cr}$ & $\operatorname{tr}$ & N/A & $\operatorname{tr}$ \\
\hline $\mathrm{Mn}$ & 0.40 & N/A & $\operatorname{tr}$ \\
\hline $\mathrm{Zn}$ & 0.55 & N/A & $\operatorname{tr}$ \\
\hline I & 0.13 & N/A & N/A \\
\hline $\mathrm{Fe}$ & 0.68 & 0.20 & 0.26 \\
\hline $\mathrm{Se}$ & N/A & N/A & $\operatorname{tr}$ \\
\hline
\end{tabular}

tr: traces, N/A: not available

Table 5. The C. vulgaris vitamins profile.

\begin{tabular}{lccc}
\hline \multirow{2}{*}{ Vitamins } & \multicolumn{3}{c}{ Content $\left(\mathrm{mg} .100 \mathrm{~g}^{-1}\right)$} \\
\cline { 2 - 4 } & Panahi et al. $[91]$ & Maruyama et al. $[92]$ & Yeh et al. [96] \\
\hline B2 (Riboflavin) & 4.8 & 6.0 & N/A \\
B1 (Thiamine) & 1.5 & 2.4 & N/A \\
B5 (Pantothenic acid) & 1.3 & N/A & N/A \\
B3 (Niacin) & 23.8 & N/A & N/A \\
B7 (Biotin) & 191.6 & N/A & N/A \\
B6 (Pyridoxine) & 1.7 & 1.0 & N/A \\
B12 (Cobalamin) & 125.9 & tr & N/A \\
B9 (Folicacid) & 26.9 & N/A & 13.2 \\
A (Retinol) & N/A & N/A & 2787.0 \\
E (Tocopherol) & N/A & 20.0 & 39.0 \\
C (Ascorbicacid) & 15.6 & 100.0 & \\
\hline
\end{tabular}

tr: traces, N/A: not available 
human [93]. Vitamin profile is very sensitive to outgrowth circumstances, where the highest concentration was carried out with $10 \%$ carbon dioxide after $24 \mathrm{~h}$ of autotrophic growth, while the content of vitamins was greater in autotrophic growth than in vitamins in heterotrophic conditions, because of the glucose present in the medium, as well as the use of carbon as a supplier of energy, to create various organic components $[89,90,95-99]$. The latest likely explanation of the large vitamin amounts may be due to the changes in the photosynthesis infrastructure discovered, where it is associated with alterations in cellular components.

\section{Microalgae Drying}

The biomass of the microalgae is harvested after planting while continuing downstream processing procedures. Solar energy can be considered the main method for drying biomass, however, we always need more time and more space to complete the drying process effectively and optimally [100]. Hydrothermal treatment is an important strategy for drying the biomass of the algae. Microalgae are subjected to particular temperatures and pressures to separate biomass.

\section{Extraction Techniques of Microalgae Oil}

The first technology is using a solvent that is added to the wet biomass such as methanol, chloroform, and dimethyl ether. The second technology is ultrasound which is used to break down the walls of algae cells, so the molecules of the oil can migrate from inside the cells to the side of the solvent [101]. In general, the process of extracting the bio-oil from various types of microalgae using solvents is simple, efficient, and low-cost, and does not require high energy. The hexane soxhlet extractor is considered a common technique to extract the crude bio-oil from microalgae. Figure 2 is the schematic diagram of the soxhlet apparatus used to extract the crude bio-oil of the microalgae.

\section{Microalgae Biofuel Production Tech- niques}

The extracted biofuels from the microalgae can be fuel for jet aircraft. To get the microalgae jetting fuel, there are several stages for the biomass to be converted into a liquid state, the most processes of these stages are the pyrolysis of the biomass, gasification, hydrothermal liquefaction technique, the fermentation of the biomass, hydrodeoxygenation, and deoxygenation technique. Several of these techniques have fulfilled ASTM certification based on their competence and readiness to be a substitute for fossil jet fuel and the opportunity to present them to the aviation sector. However, there are many studies and serious attempts to make this biofuel less expensive and more efficient by using special catalysts with these techniques in different operation conditions [103].

\subsection{Thermal Pyrolysis Technique}

The thermal pyrolysis process occurs in absence of oxygen. To enhance the quality of the extracted oil the zeolite is used as a catalyst. The function of zeolite is to reduce oxygen and increase the aromatic content. Compared with non-catalytic pyrolysis, the catalyst used in this process generates high-quality oil. This method may be effective for the microalgae biomass, but before this process, we need to dry the biomass well. This is an additional cost that needs to be considered, this process should be improved and reduced its cost [103].

\subsection{Gasification Technique}

The microalgae biomass is undergoing gasification as a first step, where the synthesis gas is generated at a pressure of 10 bar to 40 bar, the temperatures ranging from $150{ }^{\circ} \mathrm{C}$ to 300 ${ }^{\circ} \mathrm{C}$, with the special catalyst such as $\mathrm{Co}, \mathrm{Ni}$, or $\mathrm{Fe}$ [103]. This method is as well known as gasification/Fischer-Tropsch synthesis (GFT), this method produces expanded chains of al-

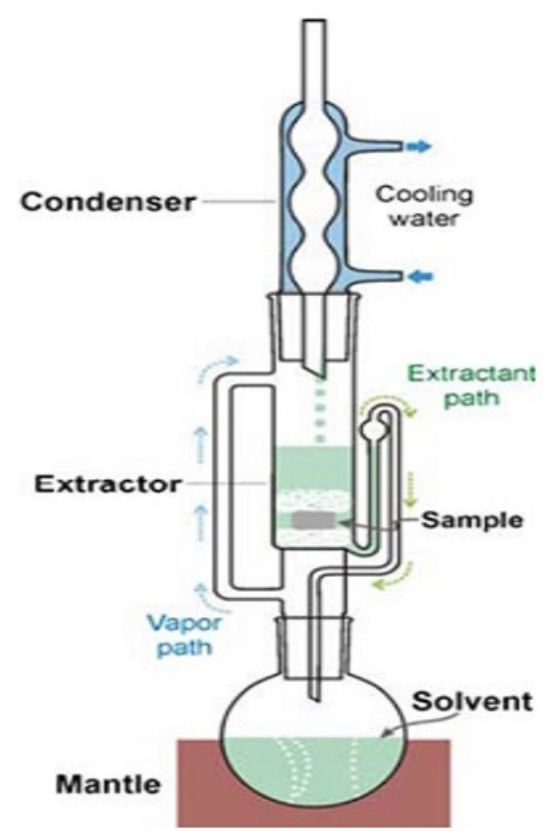

Figure 2. The schematic diagram of the soxhlet apparatus [104]. 
kanes. However, large quantities of biofuels were not generated by using microalgae biomass in this way.

\subsection{Hydrothermal Liquefaction Technique}

This process is thermochemical, it can be performed using medium temperatures under high pressure to generate the oil from the biomass of algae. The large molecules of the biomass of algae are essentially decomposed during this stage as they are divided into minimal molecules. Also, sometimes unsteady small molecules may clump together and combine to produce larger molecules [104].

\subsection{Fermentation Technique}

The fermentation of anaerobic microalgae biomass can result in the production of fuels consisting primarily of alkanes. Enzymes promote the cleavage of bonds in molecules by adding water during the enzymatic degradation process. The bioconversion transforms a section of the microalgae biomass into sugars and turns into alcohol after the fermentation. To obtain jet fuel with the required chemical and physical properties, product purification, hydrocracking, and hydroprocessing are used as a necessary measure in the final stages of production. During this method, the biomass of the sugar molecules is digested from microalgae, where intermediate alcohol is produced using enzymes. It is often difficult to convert alcohol into alkanes directly. Therefore, to achieve this transformation, we need two successive steps [105].

\subsection{Hydrodeoxygenation and Deoxygenation} Technique

One option to convert microalgae crude oil into green hydrocarbons is the catalytic deoxygenation process (DO). The process of decarbonylation and decarboxylation (DCO) and the process of Hydrodeoxygenation (HDO) are the main methods of converting microalgae crude oil in the liquid phase into hydrocarbons, while the main reactions in the vapor phase are methane production and water gas shift (WGS). Using this technology allows using the existing infrastructure of the oil refinery, which adds additional benefits for this technology. The theoretical yield of hydrocarbons for a full HDO response is $85 \%$, while DCO is $80 \%$. Both processes HDO and DCO generate pure biofuels containing hydrocarbons that share similar properties to oil-based fuels [106,107]. As a result, the catalytic de-oxygenation strategy will be cost-effective and energy-efficient to convert microalgae oil into green hydrocarbons.

9.6 Simultaneous Isomerization, Cracking, and Deoxygenation Technique

To solve the problems associated with the technique in the previous section to be suitable for the jet fuel sector. Therefore, the hydrocarbons used to be more branched and cyclized, and the subsequent isomeric step is urgently needed. For isomers and cracking responses, the heterogeneous acid catalysts are promising $[108,109]$. Zeolite is very common and very important because it offers excellent catalytic activity. Due to its acidic character, zeolite is considered a catalyst in isomerization processes. Cracking, deoxygenation, and isomerization are important concerns for the industry as this pathway can help reduce production costs [110]. This will make the use of biogasoline, biokerosene, and biodiesel possible and meet the new and essential requirements of the aviation and highway industries with significant environmental benefits.

\subsection{HZSM-5 Zeolite Modifications}

Many studies were conducted to obtain biofuel from algal biomass in the catalytic processes using different types of zeolites. Numerous researches have involved the manufacture and diagnosis of mesoporous zeolite and the possibility of its use in various catalytic reactions, it has shown great efficacy in the biofuel production from biomass. Mesoporous materials have proven effective in many reactions including the production of biofuels, for example, mesoporous zeolite and aluminum incorporated silica, this study clarified the possibility of the spread of the reactants within the pores of the catalyst used and thus obtaining high yield percent [111]. Most studies have shown that HZSM-5 is a very promising catalyst in achieving the highest hydrocarbon contents in pyrolysis oil derived from biomass because it contains a porous system of winding channels that intersect with other channels and perpendicular to each other, allowing oxygen to circulate and thus reach sites active acids along with the pores [112,113]. The structure of the biomass is mainly composed of the $\mathrm{C}-\mathrm{C}$ and $\mathrm{C}-\mathrm{O}$ bonds, and these bonds can be broken down by the acidic sites of the HZSM-5 zeolite catalyst. Therefore, the cracking, isomerization, and deoxygenation processes will be very effective in biofuel production processes from biomass [114]. 


\subsubsection{Rare Earth Doping of HZSM-5 Zeolite}

The modified HZSM-5 with rare earth metals such as (Ce, Eu, Sm, Pr, Nd, Gd, and La) has a great advantage in enhancing the selectivity of the light olefins, this increases olefins production and significantly reduces the production of aromatic substances in the catalytic butane cracking process [115].

\subsubsection{Phosphorus Doping of HZSM-5 Zeolite}

The catalytic cracking technique of alkanes (C4) is used to produce light olefins over the phosphorous doped HZSM-5. However, favorable results were obtained by impregnating with aqueous solutions of $\mathrm{La}\left(\mathrm{CH}_{3} \mathrm{COO}\right)_{3} \cdot 1.5 \mathrm{H}_{2} \mathrm{O}$ and $\left(\mathrm{NH}_{4}\right)_{2} \mathrm{HPO}_{4}$ respectively, over $2 \%$ phosphorus$10 \% \mathrm{La} / \mathrm{HZSM}-5(\mathrm{Si} / \mathrm{Al}=200)$ zeolite [116]

\subsubsection{Different Si/Al Ratio for HZSM-5}

The acidity of zeolite mainly depends on the ratios of molar $\mathrm{Si} / \mathrm{Al}$ and the presence of modified promoters [117]. The low aluminum amount in the (ZSM-5) frame decreases the amount of (Al) recovery of the frame construction and decrease the breakdown of the frame through the treatment of the steam, which increases the steadiness of the crystalline grid with a (Si/Al ratio) [118]. In general, when raising the $\mathrm{Si} / \mathrm{Al}$ ratios, production of Benzee, Toluene, and Xylene (BTX) in all samples will be reduced, thus reducing the transfer of hydrides and aromatization by keeping the number of acidic sites small.

\subsection{Advantages and Disadvantages of the Bio- mass Generations}

There are four biofuels generations, the first generation of biofuels was obtained through the use of edible oil plants such as palm, rapeseed, sunflower, coconut, soybean, etc., both biodiesel and biofuel are manufactured in the first generation [119,120]. Because of the potential to compete with global food production [121]. Many non-food feedstocks, such as waste cooking oils (WCO) and industrial wastes, have been effectively converted to biodiesel or bioethanol (known as second-generation biofuels), but dependence on these species as a feedstock for biofuels is still limited [122]. Therefore, microalgae are proposed to be one of the most promising options (so-called third-generation feedstocks), because of photosynthesis, increased growth rate, ease of growth, and most importantly, their cultivation does not compete with land suitable for growing food crops. How- ever, the low-fat content of microalgae is often accompanied by a high and rapid growth rate.

The main reasons why is the microalgae biomass preferred for the production of biofuels are (1) Its potential to achieve high biomass, (2) Its ability to produce high fats, (3) The ease of growth on soil unsuitable for agriculture, (4) Capture carbon dioxide in large quantities, and (5) Its ability to grow on wastewater. The chemical composition of microalgae varies from one species to another, and the conditions for microalgae cultivation also affect their chemical composition. In general, microalgae cells consist of $20-40 \%$ fat, $30-50 \%$ proteins, $0-20 \%$ carbohydrates, $0-5 \%$ nucleic acids [123]. The authors have done much experimental work on the utilization of Lanthanum and Cerium on the surface of HZSM- 5 zeolite that showed a higher yield of biofuel from the crude oil of $C$. vulgaris microalgae (unpublished results).

\section{Conclusions and Future Recommenda- tions}

The process of producing biofuels from microalgae faces many technical and economic challenges. There are many attempts to develop the production of biofuels, where there are many studies on this subject, especially in the private sector on the possibility of obtaining more quantities of biofuels, especially aviation fuel, but the economic and technical details are very confidential. In general, biofuel extracted from microalgae used in the aviation sector is a promising alternative to fossil fuels. There are many types of microalgae, which are considered as raw materials for the production of aviation fuel are mentioned in the literature. There are many ways and techniques to grow these algae under special conditions to produce them in large quantities and at a reasonable cost. In general, the production of biofuels in large quantities requires many improvements to the current methods used to obtain higher production at a low cost. One of the major challenges associated with the extraction of biofuels from microalgae is that biofuels derived from these processes should have better properties than fossil fuels used in terms of their environmental impact to contribute to reducing global warming. C. vulgaris microalgae have great benefits and a promising future in this field due to their high-fat content.

The use of catalysts in the production processes of biofuels from microalgae, such as zeolite (ZSM-5), is highly effective in the deoxygenation reaction. The deoxygenation reaction has been proven as an effective process during 
DCO, HDO, and other catalytic processes producing various types of biofuels such as green jet fuel, green gasoline, and green diesel. The use of catalyst HZSM- 5 is highly effective in hydrocarbon catalytic cracking processes, especially at a temperature of $550-650{ }^{\circ} \mathrm{C}$ that is lower than steam cracking. The rare earth metals were found to an effective enhancement in the activity, selectivity, and stability of the zeolite material when added to the surface.

Genetic modification for special types of microalgae may be the real choice for reducing the cost of raw material in the biofuel production process. Each rare earth metal on the surface of zeolite has a special effect on the catalytic activity of zeolite. Therefore, the selectivity, stability, and activity of zeolite can change with the change of the rare earth metal that will be added to the zeolite surface. The percentages of the addition of rare earth metals to the surface of zeolites maybe play a major role in improving the catalytic effectiveness of zeolites in the biofuel production processes. The catalytic zeolite efficiency may be improved when adding two rare earth metals with a special percent on the zeolite surface to enhance the production of biofuel processes.

\section{Acknowledgments}

Many thanks to the Malaysian Ministry of Education (MOE) and Universiti Teknologi Malaysia for the Research University grant (Q JI30000.2546.19H46) and to my supervisors for their unlimited support and great help to accomplish this research.

\section{References}

[1] Baamran, K.S., Tahir, M., Mohamed, M., Khoja, A.H. (2020). Effect of support size for stimulating hydrogen production in phenol steam reforming using Ni-embedded $\mathrm{TiO} 2$ nanocatalyst. Journal of Environmental Chemical Engineering, 8(1), 103604. DOI: 10.1016/j.jece.2019.103604.

[2] Biller, P., Ross, A. (2011). Potential yields and properties of oil from the hydrothermal liquefaction of microalgae with different biochemical content. Bioresource Technology, 102(1), 215-225. DOI: 10.1016/j.biortech.2010.06.028.

[3] Srifa, A., Chaiwat, W., Pitakjakpipop, P., Anutrasakda, W., Faungnawakij, K. (2019). Advances in bio-oil production and upgrading technologies. In M. Rai, A.P. Ingle (Editors) Sustainable Bioenergy, Elsevier. pp. 167-198. DOI: 10.1016/B978-0-12-817654-2.00006-X.
[4] Peng, B., Yao, Y., Zhao, C., Lercher, J.A. (2012). Towards quantitative conversion of microalgae oil to diesel-range alkanes with bifunctional catalysts. Angewandte Chemie International Edition, 51(9), 2072-2075. DOI: 10.1002/anie.201106243.

[5] Voloshin, R.A., Rodionova, M.V., Zharmukhamedov, S.K., Veziroglu, T.N., Allakhverdiev, S.I. (2016). Biofuel production from plant and algal biomass. International Journal of $\mathrm{Hy}$ drogen Energy, 41(39), 17257-17273. DOI: 10.1016/j.ijhydene.2016.07.084.

[6] Choo, M.-Y., Oi, L.E., Ling, T.C., Ng, E.-P., Lee, H.V., Juan, J.C. (2020). Conversion of Microalgae Biomass to Biofuels. In Abu Yousuf (Editor) Microalgae Cultivation for Biofuels Production. Elsevier. pp. 149-161. DOI: 10.1016/B978-0-12-817536-1.00010-2.

[7] Ansah, E., Wang, L., Zhang, B., Shahbazi, A. (2018). Catalytic pyrolysis of raw and hydrothermally carbonized Chlamydomonas debaryana microalgae for denitrogenation and production of aromatic hydrocarbons. Fuel, 228, 234-242. DOI: 10.1016/j.fuel.2018.04.163.

[8] Zainan, N.H., Srivatsa, S.C., Li, F., Bhattacharya, S. (2018). Quality of bio-oil from catalytic pyrolysis of microalgae Chlorella vulgaris. Fuel, 223, 12-19. DOI: 10.1016/j.fuel.2018.02.166.

[9] Du, X., Gao, X., Zhang, H., Li, X., Liu, P. (2013). Effect of cation location on the hydrothermal stability of rare earth-exchanged Y zeolites. Catalysis Communications, 35, 1722. DOI: 10.1016/j.catcom.2013.02.010

[10] Baugis, G.L., Brito, H.F., de Oliveira, W., de Castro, F.R., Sousa-Aguiar, E.F. (2001). The luminescent behavior of the steamed EuY zeolite incorporated with vanadium and rare earth passivators. Microporous and Mesoporous Materials, 49(1-3), 179-187. DOI: 10.1016/S1387-1811(01)00416-4.

[11] Trigueiro, F., Monteiro, D., Zotin, F., SousaAguiar, E.F. (2002). Thermal stability of Y zeolites containing different rare earth cations. Journal of Alloys and Compounds, 344(1-2), 337-341. DOI: 10.1016/S0925-8388(02)00381$\mathrm{X}$.

[12] Nery, J.G., Giotto, M.V., Mascarenhas, Y.P., Cardoso, D., Zotin, F.M.Z., Sousa-Aguiar, E. F. (2000). Rietveld refinement and solid state NMR study of Nd-, Sm-, Gd-, and Dycontaining Y zeolites. Microporous and Mesoporous Materials, 41(1-3), 281-293. DOI: 10.1016/S1387-1811(00)00304-8.

[13] Sousa-Aguiar, E.F., Camorim, V.L.D., Zotin, F.M.Z., dos Santos, R.L.C. (1998). A Fourier transform infrared spectroscopy study of La-, Nd-, Sm-, Gd-and Dy-containing Y zeolites. 
Microporous and Mesoporous Materials, 25(13), 25-34. DOI: 10.1016/S13871811(98)00169-3.

[14] Steen, E.J., Kang, Y., Bokinsky, G., Hu, Z., Schirmer, A., McClure, A., del Cardayre, S.B., Keasling, J.D. (2010). Microbial production of fatty-acid-derived fuels and chemicals from plant biomass. Nature, 463(7280), 559-562. DOI: $10.1038 /$ nature08721.

[15] Hannon, M., Gimpel, J., Tran, M., Rasala, B., Mayfield, S. (2010). Biofuels from algae: challenges and potential. Biofuels, 1(5), 763-784. DOI: $10.4155 / \mathrm{bfs} .10 .44$.

[16] Pignolet, O., Jubeau, S., Vaca-Garcia, C., Michaud, P. (2013). Highly valuable microalgae: biochemical and topological aspects. Journal of Industrial Microbiology and Biotechnology, 40(8), 781-796. DOI: 10.1007/s10295-013-1281-7.

[17] Yamamoto, M., Fujishita, M., Hirata, A., Kawano, S. (2004). Regeneration and maturation of daughter cell walls in the autosporeforming green alga Chlorella vulgaris (Chlorophyta, Trebouxiophyceae). Journal of Plant Research, 117(4), 257-264. DOI: 10.1007/s10265-004-0154-6.

[18] Němcová, Y., Kalina, T. (2000). Cell wall development, microfibril and pyrenoid structure in type strains of Chlorella vulgaris, C. kessleri, C. sorokiniana compared with C. luteoviridis (Trebouxiophyceae, Chlorophyta). Archiv fur Hydrobiologie-Supplementband Only, 136, 95-106. DOI: 10.1127/algol_stud/100/2000/95.

[19] Burczyk, J., Hesse, M. (1981). The ultrastructure of the outer cell wall-layer ofChlorella mutants with and without sporopollenin. Plant Systematics and Evolution, 138(1-2), 121-137. DOI: 10.1007/BF00984613.

[20] Kuchitsu, K., Oh-Hama, T., Tsuzuki, M., Miyachi, S. (1987). Detection and characterization of acidic compartments (vacuoles) in Chlorella vulgaris $11 \mathrm{~h}$ cells by $31 \mathrm{P}$-in vivo NMR spectroscopy and cytochemical techniques. Archives of Microbiology, 148(2), 8387. DOI: $10.1007 / \mathrm{BF} 00425353$.

[21] Chao, L. (2000). The meaning of life. BioScience, 50(3), 245-250. DOI: 10.1641/00063568(2000)050[0245:TMOL]2.3.CO;2.

[22] Ashforth, B.E., Harrison, S.H., Corley, K.G. (2008). Identification in organizations: An examination of four fundamental questions. Journal of Management, 34(3), 325-374. DOI: $10.1177 / 0149206308316059$.

[23] Brennan, L., Owende, P. (2010). Biofuels from microalgae - a review of technologies for production, processing, and extractions of biofuels and co-products. Renewable and Sustainable Energy Reviews, 14(2), 557-577. DOI: 10.1016/j.rser.2009.10.009.
[24] Přibyl, P., Cepák, V., Zachleder, V. (2013). Production of lipids and formation and mobilization of lipid bodies in Chlorella vulgaris. Journal of Applied Phycology, 25(2), 545-553. DOI: 10.1007/s10811-012-9889-y.

[25] Converti, A., Casazza, A.A., Ortiz, E.Y., Perego, P., Del Borghi, M. (2009). Effect of temperature and nitrogen concentration on the growth and lipid content of Nannochloropsis oculata and Chlorella vulgaris for biodiesel production. Chemical Engineering and Processing: Process Intensification, 48(6), 11461151. DOI: 10.1016/j.cep.2009.03.006.

[26] Lv, J.-M., Cheng, L.-H., Xu, X.-H., Zhang, L., Chen, H.-L. (2010). Enhanced lipid production of Chlorella vulgaris by adjustment of cultivation conditions. Bioresource Technology, 101(17), 6797-6804. DOI: 10.1016/j.biortech.2010.03.120.

[27] Widjaja, A., Chien, C.-C., Ju, Y.-H. (2009). Study of increasing lipid production from fresh water microalgae Chlorella vulgaris. Journal of the Taiwan Institute of Chemical Engineers, 40(1), 13-20. DOI: 10.1016/j.jtice.2008.07.007.

[28] Liu, Z.-Y., Wang, G.-C., Zhou, B.-C. (2008). Effect of iron on growth and lipid accumulation in Chlorella vulgaris. Bioresource Technology, 99(11), 4717-4722. DOI: 10.1016/j.biortech.2007.09.073.

[29] Richmond, A., Boussiba, S., Vonshak, A., Kopel, R. (1993). A new tubular reactor for mass production of microalgae outdoors. Journal of Applied Phycology, 5(3), 327-332. DOI: 10.1007/BF02186235.

[30] Chisti, Y. (2007). Biodiesel from microalgae. Biotechnology Advances, 25(3), 294-306. 10.1016/j.biotechadv.2007.02.001.

[31] Kojima, E., Zhang, K. (1999). Growth and hydrocarbon production of microalga Botryococcus braunii in bubble column photobioreactors. Journal of Bioscience and Bioengineering, 87(6), 811-815. DOI: 10.1016/S13891723(99)80158-3.

[32] Degen, J., Uebele, A., Retze, A., SchmidStaiger, U., Trösch, W. (2001). A novel airlift photobioreactor with baffles for improved light utilization through the flashing light effect. Journal of Biotechnology, 92(2), 89-94. DOI: 10.1016/S0168-1656(01)00350-9.

[33] Liang, Y., Sarkany, N., Cui, Y. (2009). Biomass and lipid productivities of Chlorella vulgaris under autotrophic, heterotrophic and mixotrophic growth conditions. Biotechnology Letters, 31(7), 1043-1049. DOI: 10.1007/s10529-009-9975-7.

[34] Martinez, F., Ascaso, C., Orus, M. (1991). Morphometric and stereologic analysis of Chlorella vulgaris under heterotrophic 
growth conditions. Annals of Botany, 67(3),

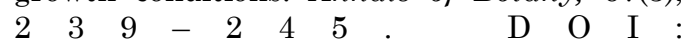
10.1093/oxfordjournals.aob.a088128.

[35] Yeh, K.-L., Chang, J.-S. (2012). Effects of cultivation conditions and media composition on cell growth and lipid productivity of indigenous microalga Chlorella vulgaris ESP-31. Bioresource Technology, 105, 120-127. DOI: 10.1016/j.biortech.2011.11.103.

[36] De-Bashan, L.E., Antoun, H., Bashan, Y. (2005). Cultivation factors and population size control the uptake of nitrogen by the microalgae Chlorella vulgaris when interacting with the microalgae growth-promoting bacterium Azospirillum brasilense. FEMS Microbiology Ecology, 54(2), 197-203. DOI: 10.1016/j.femsec.2005.03.014.

[37] De-Bashan, L.E., Bashan, Y., Moreno, M., Lebsky, V.K., Bustillos, J.J. (2002). Increased pigment and lipid content, lipid variety, and cell and population size of the microalgae Chlorella spp. when co-immobilized in alginate beads with the microalgae-growthpromoting bacterium Azospirillum brasilense. Canadian Journal of Microbiology, 48(6), 514-521. DOI: 10.1139/w02-051.

[38] Munoz, R., Guieysse, B. (2006). Algalbacterial processes for the treatment of hazardous contaminants: a review. Water research, 40(15), 2799-2815. DOI: 10.1016/j.watres.2006.06.011.

[39] Lebsky, V.K., Gonzalez-Bashan, L.E., Bashan, Y. (2001). Ultrastructure of interaction in alginate beads between the microalga Chlorella vulgaris with its natural associative bacterium Phyllobacterium myrsinacearum and with the plant growth-promoting bacterium Azospirillum brasilense. Canadian Journal of Microbiology, 47(1), 1-8. DOI: 10.1139/w00115.

[40] Leupold, M., Hindersin, S., Gust, G., Kerner, M., Hanelt, D. (2013). Influence of mixing and shear stress on Chlorella vulgaris, Scenedesmus obliquus, and Chlamydomonas reinhardtii. Journal of Applied Phycology, 25(2), 485495. DOI: $10.1007 / \mathrm{s} 10811-012-9882-5$.

[41] Morris, H.J., Almarales, A., Carrillo, O., Bermúdez, R.C. (2008). Utilisation of Chlorellavulgaris cell biomass for the production of enzymatic protein hydrolysates. Bioresource Technology, 99(16), 7723-7729. DOI: 10.1016/j.biortech.2008.01.080.

[42] Safi, C., Charton, M., Pignolet, O., Silvestre, F., Vaca-Garcia, C., Pontalier, P.-Y. (2013). Influence of microalgae cell wall characteristics on protein extractability and determination of nitrogen-to-protein conversion factors. Journal of Applied Phycology, 25(2), 523-529. DOI: $10.1007 / \mathrm{s} 10811-012-9886-1$.
[43] Servaites, J.C., Faeth, J.L., Sidhu, S.S. (2012). A dye binding method for measurement of total protein in microalgae. Analytical Biochemistry, 421(1), 75-80. DOI: 10.1016/j.ab.2011.10.047.

[44] Seyfabadi, J., Ramezanpour, Z., Khoeyi, Z.A. (2011). Protein, fatty acid, and pigment content of Chlorella vulgaris under different light regimes. Journal of Applied Phycology, 23(4), 721-726. DOI: 10.1007/s10811-0109569-8.

[45] Safi, C., Charton, M., Pignolet, O., Pontalier, P.-Y., Vaca-Garcia, C. (2013). Evaluation of the protein quality of Porphyridium cruentum. Journal of Applied Phycology, 25(2), 497-501. DOI: 10.1007/s10811-012-9883-4.

[46] Naik, S.N., Goud, V.V., Rout, P.K., Dalai, A.K. (2010). Production of first and second generation biofuels: a comprehensive review. Renewable and Sustainable Energy Reviews, $14(2), \quad 578-597$. D O I : 10.1016/j.rser.2009.10.003.

[47] Shaaban, M.M. (2001). Green microalgae water extract as foliar feeding to wheat plants. Pakistan Journal of Biological Sciences, 4(6), 628-632. DOI: 10.3923/pjbs.2001.628.632.

[48] Bajguz, A. (2000). Effect of brassinosteroids on nucleic acids and protein content in cultured cells of Chlorella vulgaris. Plant Physiology and Biochemistry, 38(3), 209-215. DOI: 10.1016/S0981-9428(00)00733-6.

[49] Rausch, T. (1981). The estimation of microalgal protein content and its meaning to the evaluation of algal biomass I. Comparison of methods for extracting protein. Hydrobiologia, $\quad 78(3), \quad 237-251$. D O I : $10.1007 / \mathrm{BF} 00008520$.

[50] López, C.V.G., García, M.d.C.C., Fernández, F.G.A., Bustos, C.S., Chisti, Y., Sevilla, J.M.F. (2010). Protein measurements of microalgal and cyanobacterial biomass. Bioresource Technology, 101(19), 7587-7591. DOI: 10.1016/j.biortech.2010.04.077.

[51] Lourenço, S.O., Barbarino, E., De-Paula, J.C., Pereira, L.O.d.S., Marquez, U.M.L. (2002). Amino acid composition, protein content and calculation of nitrogen-to-protein conversion factors for 19 tropical seaweeds. Phycological Research, 50(3), 233-241. DOI: 10.1046/j.1440-1835.2002.00278.x.

[52] Lourenço, S.O., Barbarino, E., Lavín, P.L., Lanfer Marquez, U.M., Aidar, E. (2004). Distribution of intracellular nitrogen in marine microalgae: calculation of new nitrogen-toprotein conversion factors. European Journal of Phycology, 39(1), 17-32. DOI: $10.1080 / 0967026032000157156$. 
[53] Lourenço, S.O., Barbarino, E., Marquez, U. M.L., Aidar, E. (1998). Distribution of intracellular nitrogen in marine microalgae: basis for the calculation of specific nitrogen-to-protein conversion factors. Journal of Phycology, 34(5), 798-811. DOI: 10.1046/j.1529-8817.1998.340798.x.

[54] Becker, E.W. (1994). Microalgae: biotechnology and microbiology. Cambridge University Press

[55] Borghans, L., Duckworth, A.L., Heckman, J.J., Ter Weel, B. (2008). The economics and psychology of personality traits. Journal of Human Resources, 43(4), 972-1059. DOI: 10.3368/jhr.43.4.972.

[56] Hu, Q., Sommerfeld, M., Jarvis, E., Ghirardi, M., Posewitz, M., Seibert, M., Darzins, A. (2008). Microalgal triacylglycerols as feedstocks for biofuel production: perspectives and advances. The Plant Journal, 54(4), 621-639. DOI: 10.1111/j.1365-313X.2008.03492.x.

[57] Bharadwaj, S.V., Ram, S., Pancha, I., Mishra, S. (2020). Recent Trends in Strain Improvement for Production of Biofuels From Microalgae. In Abu Yousuf (Editor) Microalgae Cultivation for Biofuels Production. Elsevier. pp. 211-225. DOI: 10.1016/B978-0-12-817536$1.00014-\mathrm{X}$.

[58] Zheng, H., Yin, J., Gao, Z., Huang, H., Ji, X., Dou, C. (2011). Disruption of Chlorella vulgaris cells for the release of biodieselproducing lipids: a comparison of grinding, ultrasonication, bead milling, enzymatic lysis, and microwaves. Applied Biochemistry and Biotechnology, 164(7), 1215-1224. DOI: 10.1007/s12010-011-9207-1.

[59] Přibyl, P., Cepák, V., Zachleder, V. (2012). Production of lipids in 10 strains of Chlorella and Parachlorella, and enhanced lipid productivity in Chlorella vulgaris. Applied Microbiology and Biotechnology, 94(2), 549-561. DOI: 10.1007/s00253-012-3915-5.

[60] Lee, J.-Y., Yoo, C., Jun, S.-Y., Ahn, C.-Y., Oh, H.-M. (2010). Comparison of several methods for effective lipid extraction from microalgae. Bioresource Technology, 101(1), S75-S77. DOI: 10.1016/j.biortech.2009.03.058.

[61] Mercer, P., Armenta, R.E. (2011). Developments in oil extraction from microalgae. European Journal of Lipid Science and Technology, $\quad 113(5), \quad 539-547$. D O : 10.1002/ejlt.201000455.

[62] Phukan, M.M., Chutia, R.S., Konwar, B., Kataki, R. (2011). Microalgae Chlorella as a potential bio-energy feedstock. Applied Energy, 88(10), $\quad 3307-3312$. D O I : 10.1016/j.apenergy.2010.11.026.
[63] Olmstead, I.L., Hill, D.R., Dias, D.A., Jayasinghe, N.S., Callahan, D.L., Kentish, S.E., Scales, P.J., Martin, G.J. (2013). A quantitative analysis of microalgal lipids for optimization of biodiesel and omega-3 production. Biotechnology and Bioengineering, 110(8), 20962104. DOI: 10.1002/bit.24844.

[64] Stephenson, A.L., Dennis, J.S., Howe, C.J., Scott, S.A., Smith, A.G. (2010). Influence of nitrogen-limitation regime on the production by Chlorella vulgaris of lipids for biodiesel feedstocks. Biofuels, 1(1), 47-58. DOI: 10.4155/bfs.09.1.

[65] Lordan, S., Ross, R.P., Stanton, C. (2011). Marine bioactives as functional food ingredients: potential to reduce the incidence of chronic diseases. Marine drugs, 9(6), 10561100. DOI: $10.3390 / \mathrm{md} 9061056$.

[66] Dubois, M., Gilles, K.A., Hamilton, J.K., Rebers, P.t., Smith, F. (1956). Colorimetric method for determination of sugars and related substances. Analytical Chemistry, 28(3), 350-356. DOI: 10.1021/ac60111a017.

[67] Shi, Y., Sheng, J., Yang, F., Hu, Q. (2007). Purification and identification of polysaccharide derived from Chlorella pyrenoidosa. Food chemistry, 103(1), 101-105. DOI: 10.1016/j.foodchem.2006.07.028.

[68] Dragone, G., Fernandes, B.D., Abreu, A.P., Vicente, A.A., Teixeira, J.A. (2011). Nutrient limitation as a strategy for increasing starch accumulation in microalgae. Applied Energy, $88(10), \quad 3331-3335$. D O I : 10.1016/j.apenergy.2011.03.012.

[69] Fernandes, B., Dragone, G., Abreu, A.P., Geada, P., Teixeira, J., Vicente, A. (2012). Starch determination in Chlorella vulgarisa comparison between acid and enzymatic methods. Journal of Applied Phycology, 24(5), 1203-1208. DOI: 10.1007/s10811-011-9761-5.

[70] Takeda, H. (1988b). Classification of Chlorella strains by means of the sugar components of the cell wall. Biochemical Systematics and Ecology, 16(4), 367-371. DOI: 10.1016/03051978(88)90027-0.

[71] Takeda, H. (1988a). Classification of Chlorella strains by cell wall sugar composition. Phytochemistry, 27(12), 3823-3826. DOI: 10.1016/0031-9422(88)83025-5.

[72] Takeda, H. (1991). Sugar composition of the cell wall and the taxonomy of Chlorella (Chlorophyceae). Journal of Phycology, 27(2), 224-232. DOI: $10.1111 / \mathrm{j} .0022$ 3646.1991.00224.x.

[73] Takeda, H. (1993). Chemical composition of cell walls as a taxonomical marker. Journal of Plant Research, 106(3), 195-200. DOI: 10.1007/BF02344585. 
[74] Takeda, H., Hirokawa, T. (1984). Studies on the Cell Wall of Chlorella V.: Comparison of the Cell Wall Chemical Compositions in Strains of Chlorella ellipsoidea. Plant and Cell Physiology, 25(2), 287-295. DOI: 10.1093/oxfordjournals.pcp.a076713.

[75] Chacón-Lee, T., González-Mariño, G.E. (2010). Microalgae for "healthy" foodspossibilities and challenges. Comprehensive Reviews in Food Science and Food Safety, $9(6), \quad 655-675$. DOI: 10.1111/j.15414337.2010.00132.x.

[76] Singh, J., Gu, S. (2010). Commercialization potential of microalgae for biofuels production. Renewable and Sustainable Energy Reviews, 14(9), 2596-2610. DOI: 10.1016/j.rser.2010.06.014.

[77] Mendes, R.L., Nobre, B.P., Cardoso, M.T., Pereira, A.P., Palavra, A.F. (2003). Supercritical carbon dioxide extraction of compounds with pharmaceutical importance from microalgae. Inorganica Chimica Acta, 356, 328-334. DOI: 10.1016/S0020-1693(03)00363-3.

[78] Kitada, K., Machmudah, S., Sasaki, M., Goto, M., Nakashima, Y., Kumamoto, S., Hasegawa, T. (2009). Supercritical CO2 extraction of pigment components with pharmaceutical importance from Chlorella vulgaris. Journal of Chemical Technology \& Biotechnology: International Research in Process, Environmental \& Clean Technology, 84(5), 657-661. DOI: 10.1002/jctb.2096.

[79] Kim, S.M., Jung, Y.-J., Kwon, O.-N., Cha, K.H., Um, B.-H., Chung, D., Pan, C.-H. (2012). A potential commercial source of fucoxanthin extracted from the microalga Phaeodactylum tricornutum. Applied Biochemistry and Biotechnology, 166(7), 1843-1855. DOI: 10.1007/s12010-012-9602-2.

[80] Kong, W., Liu, N., Zhang, J., Yang, Q., Hua, S., Song, H., Xia, C. (2014). Optimization of ultrasound-assisted extraction parameters of chlorophyll from Chlorella vulgaris residue after lipid separation using response surface methodology. Journal of Food Science and Technology, 51(9), 2006-2013. DOI: 10.1007/s13197-012-0706-z.

[81] Fernández-Sevilla, J.M., Fernández, F.G.A., Grima, E.M. (2012). Obtaining lutein-rich extract from microalgal biomass at preparative scale. In José-Luis Barredo (Editor) Microbial Carotenoids from Bacteria and Microalgae. Methods in Molecular Biology (Methods and Protocols). Humana Press, Totowa, NJ. pp. 307-314. DOI: 10.1007/978-1-61779-879-5_19.

[82] Granado, F., Olmedilla, B., Blanco, I. (2003). Nutritional and clinical relevance of lutein in human health. British Journal of Nutrition, 90(3), 487-502. DOI: 10.1079/bjn2003927.
[83] Cha, K.H., Koo, S.Y., Lee, D.-U. (2008). Antiproliferative effects of carotenoids extracted from Chlorella ellipsoidea and Chlorella vulgaris on human colon cancer cells. Journal of Agricultural and Food Chemistry, 56(22), 10521-10526. DOI: 10.1021/jf802111x.

[84] Tanaka, K., Konishi, F., Himeno, K., Taniguchi, K., Nomoto, K. (1984). Augmentation of antitumor resistance by a strain of unicellular green algae, Chlorella vulgaris. Cancer Immunology Immunotherapy, 17(2), 90-94. DOI: $10.1007 / \mathrm{BF} 00200042$.

[85] Cha, K.H., Lee, H.J., Koo, S.Y., Song, D.-G., Lee, D.-U., Pan, C.-H. (2009). Optimization of pressurized liquid extraction of carotenoids and chlorophylls from Chlorella vulgaris. Journal of Agricultural and Food Chemistry, 58(2), 793-797. DOI: 10.1021/jf902628j.

[86] Görs, M., Schumann, R., Hepperle, D., Karsten, U. (2010). Quality analysis of commercial Chlorella products used as dietary supplement in human nutrition. Journal of Applied Phycology, 22(3), 265-276. DOI: 10.1007/s10811-009-9455-4.

[87] Li, H.-B., Jiang, Y., Chen, F. (2002). Isolation and purification of lutein from the microalga Chlorella vulgaris by extraction after saponification. Journal of Agricultural and Food Chemistry, 50(5), 1070-1072. DOI: 10.1021/jf010220b.

[88] Hoch, W.A., Zeldin, E.L., McCown, B.H. (2001). Physiological significance of anthocyanins during autumnal leaf senescence. Tree Physiology, 21(1), 1-8. DOI: 10.1093/treephys/21.1.1.

[89] Panahi, Y., Pishgoo, B., Jalalian, H.R., Mohammadi, E., Taghipour, H.R., Sahebkar, A., Abolhasani, E. (2012). Investigation of the effects of Chlorella vulgaris as an adjunctive therapy for dyslipidemia: Results of a randomised open-label clinical trial. Nutrition \& Dietetics, 69(1), 13-19. DOI: 10.1111/j.17470080.2011.01569.x.

[90] Maruyama, I., Nakao, T., Shigeno, I., Ando, Y., Hirayama, K. (1997). Application of unicellular algae Chlorella vulgaris for the massculture of marine rotifer Brachionus. Hydrobiologia, 358, 133-138. DOI: 10.1023/A:1003116003184.

[91] Tokuşoglu, Ö. (2003). Biomass nutrient profiles of three microalgae: Spirulina platensis, Chlorella vulgaris, and Isochrisis galbana. Journal of Food Science, 68(4), 1144-1148. DOI: $10.1111 /$ j.1365-2621.2003.tb09615.x.

[92] Lin, T.-C., Chang, F.-H., Hsieh, J.-H., Chao, H.-R., Chao, M.-R. (2002). Characteristics of polycyclic aromatic hydrocarbons and total suspended particulate in indoor and outdoor 
atmosphere of a Taiwanese temple. Journal of Hazardous Materials, 95(1-2), 1-12. DOI: 10.1016/S0304-3894(02)00146-2.

[93] King, J.W. (2003). Supercritical fluid chromatography (SFC)-global perspective and applications in lipid technology. Advances in Lipid Methodology, 5, 301-366. DOI: 10.1533/9780857097941.301.

[94] Yeh, K.L., Chang, J.S. (2011). Nitrogen starvation strategies and photobioreactor design for enhancing lipid content and lipid production of a newly isolated microalga Chlorella vulgaris ESP-31: Implications for biofuels. Biotechnology Journal, 6(11), 1358-1366. DOI: 10.1002/biot.201000433.

[95] Ochiai, S., Hase, E. (1970). Studies on chlorophyll formation in Chlorella protothecoides I. Enhancing effects of light and added $\delta$ aminoIevulinic acid, and suppressive effect of glucose on chlorophyll formation. Plant and Cell Physiology, 11(4), 663-673. DOI: 10.1093/oxfordjournals.pcp.a074552.

[96] Ogawa, T., Aiba, S. (1981). Bioenergetic analysis of mixotrophic growth in Chlorella vulgaris and Scenedesmus acutus. Biotechnology and Bioengineering, 23(5), 1121-1132. DOI: 10.1002/bit.260230519.

[97] Mallick, N., Mandal, S., Singh, A.K., Bishai, M., Dash, A. (2012). Green microalga Chlorella vulgaris as a potential feedstock for biodiesel. Journal of Chemical Technology \& Biotechnology, 87(1), 137-145. DOI: 10.1002/jctb.2694.

[98] Kotrbáček, V., Doubek, J., Doucha, J. (2015). The chlorococcalean alga Chlorella in animal nutrition: a review. Journal of Applied Phycology, 27(6), 2173-2180. DOI: 10.1007/s10811-014-0516-y.

[99] Patino, R., Janssen, M., von Stockar, U. (2007). A study of the growth for the microalga Chlorella vulgaris by photo-bio-calorimetry and other on-line and off-line techniques. Biotechnology and Bioengineering, 96(4), 757767. DOI: 10.1002/bit.21182.

[100] Packer, M. (2009). Algal capture of carbon dioxide; biomass generation as a tool for greenhouse gas mitigation with reference to New Zealand energy strategy and policy. Energy Policy, 37(9), 3428-3437. DOI: 10.1016/j.enpol.2008.12.025.

[101] Cheirsilp, B., Srinuanpan, S., Mandik, Y.I. (2020). Efficient Harvesting of Microalgal biomass and Direct Conversion of Microalgal Lipids into Biodiesel. In Microalgae Cultivation for Biofuels Production. Elsevier. pp. 83-96. DOI: 10.1016/B978-0-12-817536-1.00006-0.
[102] Dabbs, D.M., Mulders, N., Aksay, I.A. (2006). Solvothermal removal of the organic template from L3 ("sponge") templated silica monoliths. Journal of Nanoparticle Research, 8(5), 603-614. DOI: 10.1007/s11051-005-9063-4.

[103] Hileman, J.I., Donohoo, P.E., Stratton, R.W. (2010). Energy content and alternative jet fuel viability. Journal of Propulsion and Power, 26(6), 1184-1196. DOI: 10.2514/1.46232.

[104] Davis, R., Biddy, M.J., Tan, E., Tao, L., Jones, S.B. (2013). Biological conversion of sugars to hydrocarbons technology pathway. URL: https://www.energy.gov/

[105] Efremenko, E., Nikolskaya, A., Lyagin, I., Senko, O., Makhlis, T., Stepanov, N., Varfolomeev, S. (2012). Production of biofuels from pretreated microalgae biomass by anaerobic fermentation with immobilized Clostridium acetobutylicum cells. Bioresource technology, 114, 342-348.

[106] Kumar, P., Yenumala, S.R., Maity, S.K., Shee, D. (2014). Kinetics of hydrodeoxygenation of stearic acid using supported nickel catalysts: Effects of supports. Applied Catalysis A: General, 471, 28-38. DOI: 10.1016/j.apcata.2013.11.021.

[107] Ayodele, O., Farouk, H.U., Mohammed, J., Uemura, Y., Daud, W.M.A.W. (2015). Hydrodeoxygenation of oleic acid into $\mathrm{n}$-and isoparaffin biofuel using zeolite supported fluoro-oxalate modified molybdenum catalyst: Kinetics study. Journal of the Taiwan Institute of Chemical Engineers, 50, 142-152. DOI: 10.1016/j.jtice.2014.12.014.

[108] Harnos, S., Onyestyák, G., Kalló, D. (2012). Hydrocarbons from sunflower oil over partly reduced catalysts. Reaction Kinetics, Mechanisms and Catalysis, 106(1), 99-111. DOI: 10.1007/s11144-012-0424-6.

[109] Ha, L., Mao, J., Zhou, J., Zhang, Z.C., Zhang, S. (2009). Skeletal isomerization of unsaturated fatty acids on beta zeolites: effects of calcination temperature and additives. $A p$ plied Catalysis A: General, 356(1), 52-56. DOI: 10.1016/j.apcata.2008.12.018.

[110] Twaiq, F.A., Zabidi, N.A., Bhatia, S. (1999). Catalytic conversion of palm oil to hydrocarbons: performance of various zeolite catalysts. Industrial \& Engineering Chemistry Research, 38(9), 3230-3237. DOI: 10.1021/ie980758f.

[111] Li, T., Cheng, J., Huang, R., Zhou, J., Cen, K. (2016). Conversion pathways of palm oil into jet biofuel catalyzed by mesoporous zeolites. RSC Advances, 6(106), 103965-103972. DOI: 10.1039/C6RA22500D. 
[112] Veses, A., Puértolas, B., Callén, M., García, T. (2015). Catalytic upgrading of biomass derived pyrolysis vapors over metal-loaded ZSM-5 zeolites: Effect of different metal cations on the bio-oil final properties. $M i$ croporous and Mesoporous Materials, 209, $\begin{array}{llllllllllll} & 1 & 8 & 9 & - & 1 & 9 & 6 & & \text { D } & \text { O } & \text { I }\end{array}$ 10.1016/j.micromeso.2015.01.012.

[113] Aho, A., Kumar, N., Lashkul, A., Eränen, K., Ziolek, M., Decyk, P., Salmi, T., Holmbom, B., Hupa, M., Murzin, D.Y. (2010). Catalytic upgrading of woody biomass derived pyrolysis vapours over iron modified zeolites in a dualfluidized bed reactor. Fuel, 89(8), 1992-2000. DOI: 10.1016/j.fuel.2010.02.009.

[114] Shen, D., Jin, W., Hu, J., Xiao, R., Luo, K. (2015). An overview on fast pyrolysis of the main constituents in lignocellulosic biomass to valued-added chemicals: structures, pathways and interactions. Renewable and Sustainable Energy Reviews, 51, 761-774. DOI: 10.1016/j.rser.2015.06.054.

[115] Sousa-Aguiar, E.F., Trigueiro, F.E., Zotin, F.M.Z. (2013). The role of rare earth elements in zeolites and cracking catalysts. Catalysis Today, 218-219, 115-122. DOI: 10.1016/j.cattod.2013.06.021.

[116] Wakui, K., Satoh, K.-i., Sawada, G., Shiozawa, K., Matano, K.-i., Suzuki, K., Hayakawa, T., Murata, K., Yoshimura, Y., Mizukami, F. (1999). Catalytic cracking of n-butane over rare earth-loaded HZSM-5 catalysts. Journal of The Japan Petroleum Institute, 42(5), 307314. DOI: 10.1016/S0167-2991(99)80245-6.

[117] Jung, J.S., Kim, T.J., Seo, G. (2004). Catalytic cracking of n-octane over zeolites with different pore structures and acidities. Korean Journal of Chemical Engineering, 21(4), 777781. DOI: 10.1007/BF02705520.
[118] Hsu, C.-Y., Heimbuch, C., Armes, C., Gates, B. (1992). A highly active solid superacid catalyst for n-butane isomerization: a sulfated oxide containing iron, manganese and zirconium. Journal of the Chemical Society, Chemical Communications, (22), 1645-1646. DOI: 10.1039/C39920001645.

[119] Rahimi, N., Karimzadeh, R. (2011). Catalytic cracking of hydrocarbons over modified ZSM5 zeolites to produce light olefins: A review. Applied Catalysis A: General, 398(1-2), 1-17. DOI: 10.1016/j.apcata.2011.03.009.

[120] Zhang, F., Fang, Z., Wang, Y.-T. (2015). Biodiesel production directly from oils with high acid value by magnetic $\mathrm{Na}_{2} \mathrm{SiO}_{3} @ \mathrm{Fe}_{3} \mathrm{O}_{4} / \mathrm{C}$ catalyst and ultrasound. Fuel, 150, 370-377. DOI: 10.1016/j.fuel.2015.02.032.

[121] Parmar, A., Singh, N.K., Pandey, A., Gnansounou, E., Madamwar, D. (2011). Cyanobacteria and microalgae: a positive prospect for biofuels. Bioresource Technology, $102(22), \quad 10163-10172$. D O I : 10.1016/j.biortech.2011.08.030.

[122] Alalwan, H.A., Alminshid, A.H., Aljaafari, H.A. (2019). Promising evolution of biofuel generations. Subject review. Renewable Energy Focus, 28, 127-139. DOI: 10.1016/j.ref.2018.12.006.

[123] Chang, S.H. (2018). Bio-oil derived from palm empty fruit bunches: Fast pyrolysis, liquefaction and future prospects. Biomass and Bioenergy, $119, \quad 263-276$. D O : 10.1016/j.biombioe.2018.09.033.

Selected and Revised Papers from International Conference on Sustainable Energy and Catalysis 2021 (ICSEC 2021) (https://engineering.utm.my/chemicalenergy/icsec2021/) (School of Chemical and Energy Engineering, Faculty of Engineering, Universiti Teknologi Malaysia, 16-17th February 2021) after Peer-reviewed by Scientific Committee of ICSEC 2021 and Peer-Reviewers of Bulletin of Chemical Reaction Engineering \& Catalysis.

Editors (Guest) in this ICSEC 2021 section are Nor Aishah Saidina Amin, Mohd Asmadi Mohammed Yussuf, Salman Raza Naqui, while Editor in Chief is I. Istadi. 